\section{Climate Change and Health}

\author{
Dara V. Gaeva ${ }^{1}$, Galina M. Barinova ${ }^{2}$ and \\ Eugene V. Krasnov ${ }^{2}$ \\ ${ }^{1}$ Service for Organization of Scientific Research \\ Activity, Immanuel Kant Baltic Federal \\ University, Kaliningrad, Russia \\ ${ }^{2}$ Institute of Environmental Management, Urban \\ Development and Spatial Planning \\ (IEMUD\&SP), Immanuel Kant Baltic Federal \\ University, Kaliningrad, Russia
}

\section{Definition of the Subject}

According to WHO Health is a state of complete physical, mental, and social well-being and not merely the absence of disease or infirmity (WHO 2018b).

As a result of global climate change, people in many regions of the globe are increasingly falling ill and even dying as a result of the indirect and direct impact of extreme events. Tropical cyclones, hurricanes, floods, droughts, heat and cold waves annually take many lives and promoting the spread of natural focal, transmissible diseases, exacerbation of chronic pulmonary, cardiovascular, and other diseases. Extreme climatic phenomena adversely affect not only the physical, but also the psychological state of the population, reduce economic efficiency, and cause political tensions and conflicts.

\section{Introduction}

People's health is inextricably linked with many social and economic factors, the quality of air, water, food, as well as climate and weather conditions in various regions of the globe. In the context of modern global climate change, people are increasingly falling ill or dying as a result of indirect effects of extreme weather events (heat waves and cold waves, droughts, floods, hurricanes, etc.).

When solving the actual problem of the impact of global climate change on the spread of diseases, an interdisciplinary approach is needed. This is especially true of infectious and vector-borne diseases characteristic of tropical countries, as well as the possibility of spreading exotic diseases such as 3-day malaria, chikungunya fever, Dengue fever, West Nile fever, etc.

There is concern about the increased risk of diseases such as cholera, leptospirosis; they are transmitted through water, since high temperatures of air and an increase in the amount of precipitation create favorable conditions for the development of pathogens.

Meteorological factors such as temperature, cloudiness, frequency, and intensity of precipitation, wind speed are first-rate drivers that affect air quality, determining the rate of photochemical reactions, vertical mixing, horizontal transport, biogenic emissions, and the rate of removal of pollutants by wet and dry deposition. In the United States, climate change is likely to increase the 
ozone content in the surface atmosphere in much of the country by 2030 and will cause a growth of early deaths and acute respiratory symptoms (Fann et al. 2014).

External conditions, life circumstances of each person, specific causes of the emergence, and development of diseases are called risk factors. Among them are: (1) natural conditions (climate, water, soil, plants and wildlife); (2) way of life and socio-economic conditions; (3) degradation and pollution of the environment; (4) production conditions. According to $\mathrm{WHO}$, the health is affected by habitat for $20 \%$, for $50 \%$ the way of life, heredity $20 \%$, the quality of health care $10 \%$.

People's behavior makes a greater contribution to DALY (28\%) than metabolism (19\%), environmental and occupational risks (5\%). But environmental risks, such as air pollution, require special consideration within the framework of the national public health policy being implemented (Newton et al. 2015).

There are certain regularities both in the course of time in the processes characterizing climate change and in the individual reaction of the organism to them. A large role is played by the factor of the multiplicity of the impact of various factors simultaneously. There is a growing need to compile information on the main threats to the spread of diseases, including infectious diseases associated with climate change. In this entry, we discuss the results of modeling climate changes for the twentyfirst century, the adverse effects in the health of the population when exposed to climatic factors (pathogens, allergens, mental health, and infections). Particular attention is paid to the regional aspects of climate change and factors whose influence is demonstrably measurable and effective preventive measures can be developed for them.

This review of current research from various areas of knowledge on the interaction of humans and the climate system shows that climate change processes affect all components of human health, including mental health. Increasing the health impact of climate change is happening globally. Some effects are stable and can manifest themselves in the human health condition for a long time after unfavorable weather events (hurricanes, droughts, floods, etc.).

\section{Global Warming and Health}

After the publication of the first IPCC report (1990), the projections showed for 1990-2005 an increase in the global mean temperature between approximately 0.15 and $0.3{ }^{\circ} \mathrm{C}$ per decade. Model experiments show that even if all the radiation factors remained constant at 2000 levels, then in the next two decades there would be warming at a rate of about $0.1{ }^{\circ} \mathrm{C}$ per decade, due to the slow response of the oceans. Continuation of greenhouse gas emissions by existing or faster rates would cause further warming and would lead to many changes in the global climate system in the twenty-first century, which would very likely be more significant than those observed in the twentieth century (IPCC 2007) (Fig. 1).

According to the long-term estimates of the Fifth Assessment Report of the IPCC, the change in global surface air temperature for the period 2016-2035 compared to 1986-2005 will be in the range $0.3-0.7{ }^{\circ} \mathrm{C}$ (medium confidence); in comparison with the period 1850-1900, the excess will be $1.5-2.0^{\circ} \mathrm{C}$ (high degree of reliability). The change in the amount of precipitation will not be homogeneous. In high latitudes and the equatorial part of the Pacific Ocean, an increase in the average annual precipitation is likely. In many arid regions of the mid-latitudes and in the subtropics, the average amount of precipitation is likely to decrease, while in the humid regions in the middle latitudes, it will increase. The variability and recurrence of extreme precipitation events over most of the land in the mid-latitudes and over humid tropical regions is very likely to increase (IPCC 2013).

In the twenty-first century, the shift of climatic zones, an increase in the number of extreme weather events, and, as a result, an increase in the negative impact of climate change on human health, is foreseen. The consequences associated with an increase in air temperature, an increase in the number of very hot days, especially in temperate latitudes, will adversely affect the most sensitive groups of the population (children, old people, chronic patients with high blood pressure, etc.). 

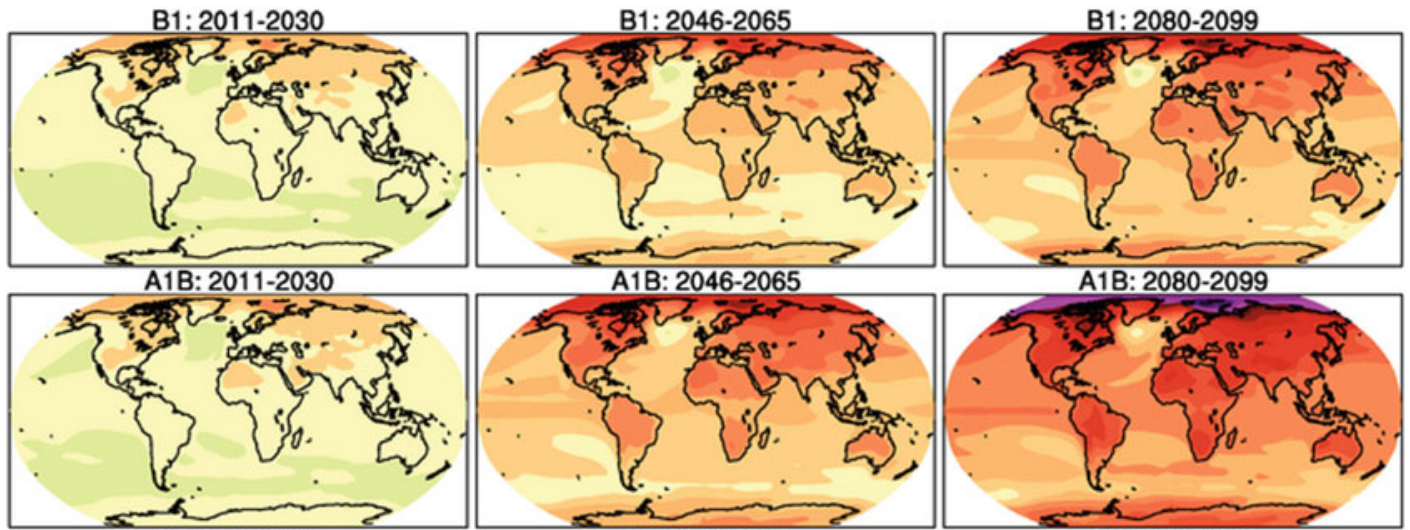

A2: $2011-2030$

A2: 2046-2065

A2: 2080-2099

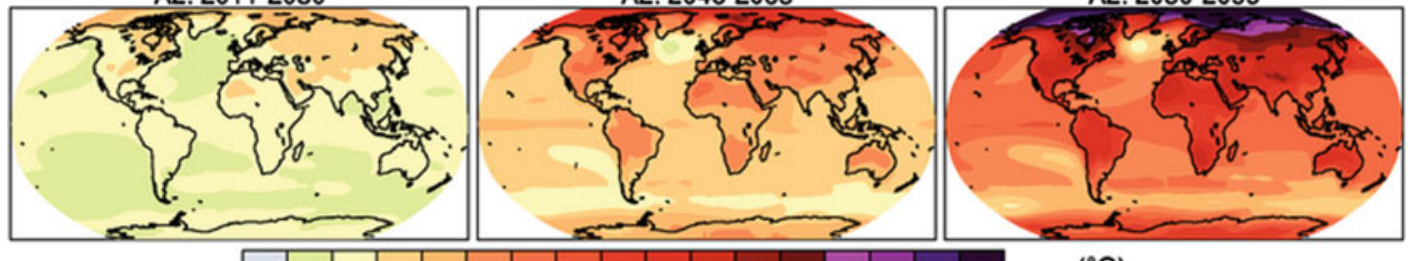

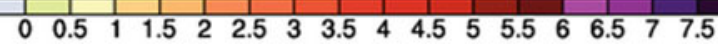

$\left({ }^{\circ} \mathrm{C}\right)$

Climate Change and Health, Fig. 1 Multi-model mean of annual mean surface warming (surface air temperature change, ${ }^{\circ} \mathrm{C}$ ) for the scenarios B1 (top), A1B (middle) and A2 (bottom), and three time periods, 2011 to 2030 (left),

The possible growth of weather instability with sharp changes in atmospheric pressure, humidity, and air temperature will lead to an increase in the mortality of elderly people sensitive to stress. The destruction of the ozone layer will contribute to more ultraviolet radiation that reach the earth's surface and can affect the increase in the number of cases of skin cancer and eye diseases. The climate change will be impact an infectious diseases that are transmitted through air, water, soil, food such as cholera, dysentery, hepatitis, poliomyelitis, and others. A particular danger is the change in the productivity of pathogens: fungi mold, etc., and the effectiveness of the action of biotoxins at high temperature. Climate change will have a significant impact on the geography of vector-borne diseases distribution of which depends on biological vectors (mosquitoes and other insects).

High air temperature and precipitation create favorable conditions for the emergence of additional breeding sites for mosquitoes. In 2010, there were 216 million malaria cases worldwide,
2046 to 2065 (middle) and 2080 to 2099 (right). Anomalies are relative to the average of the period 1980 to 1999 (Meehl 2007)

with 655,000 deaths, mainly in Africa (WHO 2011).

Summarizing the current data of the medical statistics of WHO, WMO, etc., it can be concluded that in connection with the growth of threats of climatic factors, will be spreading airborne infections (leptospirosis, meningitis) and transmissive (malaria) diseases, as well as noninfectious diseases of organs and systems that plays barrier function in the interaction of human to environment.

\section{Heat Waves and Droughts}

In many countries, there is an increase in mortality and morbidity in people during or immediately after the heat wave. First of all, it concerns the older generation and people with chronic diseases of the circulatory and respiratory organs. Especially if during the heat waves there is an increase in the level of air pollution. Such situations arise regularly in many countries of the world. In recent 
years, the influence of heat waves on health is manifested in India, China, South Korea, Japan, Thailand, Israel, and Mediterranean countries, as well as in Mexico. More and more such tragedies occur in more northern latitudes - in the USA, Canada, Scandinavian countries (Kokorin 2014). There is a so-called "optimal" temperature, at which mortality is minimal. This value depends on the climatic characteristics of the region - its value is higher the warmer the climate. Thus, in the Netherlands the threshold for this value is $16.5{ }^{\circ} \mathrm{C}$, in Arkhangelsk and Moscow $18{ }^{\circ} \mathrm{C}$, in Montreal $21{ }^{\circ} \mathrm{C}$, and in Brisbane $24{ }^{\circ} \mathrm{C}$, etc. (Grigoŕyeva 2014).

For example, in all regions of England, the risk of death, associated with both heat and cold, is significantly increased. Older people are at greatest risk. In the absence of adaptation, mortality from heat intolerance by the 2050s is expected to increase by about $257 \%$ from the current annual baseline, and mortality from cold will decrease by $2 \%$. The increase in the number of future temperature-related deaths is partly due to projected population growth and aging (Hajat et al. 2014).

An analysis of the relationship between climate and human health indicates the need for protective measures in relation to health risks associated with climate. Increased temperature and lack of drink water increase the risk of dehydration-related kidney diseases, including kidney stones, heat stroke, etc. Hyperosmolarity especially can also increase the risk of obesity and diabetes. In synergy with diets high in fructose-containing sugars, salt, and purine-rich foods, the epidemic of obesity and diabetes are accelerating (Johnson et al. 2016).

Long-term droughts, especially accompanied by strong winds that carry dust, sand and other substances, forest fires, and grassy fires, have a negative impact on people with skin and respiratory diseases, bronchial asthma, etc. For example, skin diseases cause a great strain in the global context of health and remain the 18th leading cause of the global burden of health (Hay et al. 2014).

\section{Spread of Pathogens}

Problems for public health go far beyond the obvious direct impact during natural disasters: floods, storms, typhoons, etc. They lead to epidemics, mass diseases caused by poor water quality and activation of pathogens of many infections and parasitic diseases due to high temperatures and high air humidity. In conditions of rapid warming, there is a risk of more human infections, and especially outbreaks associated with extreme weather events, such as heat waves in Northern Europe.

Using the analysis of epidemiological time series, relationships between three hydro-climatic variables (temperature, precipitation, and flow) and acute gastrointestinal diseases (AGI) were studied in two communities in British Columbia, Canada. The number of monthly cases of AGI increased with increasing temperature and precipitation (Galway et al. 2015).

Pathogenic gram-negative bacteria, including the species Vibrio vulnificus and Vibrio parahaemolyticus, are a globally important cause of diseases in humans and aquatic animals. In conditions of rapid warming, there is a risk of more human infections, and especially outbreaks associated with extreme weather events, such as heat waves in Northern Europe. Since the growth of pathogenic vibrios in the natural environment is largely determined by temperature, this group of pathogens is an important and tangible barometer of climate change (Baker-Austin et al. 2017).

In South and South-East Asia, outbreaks of cholera coincide with an increase in water temperature, including those caused by El Niño. According to some calculations in the tropics and subtropics in the second half of the twentyfirst century, it is possible that diseases of the gastrointestinal system by $15-30 \%$ will be increased (IPCC 2013).

Diseases transmitted by insects, ticks, rodents also become more global and widely spread with increasing temperature.

Two hundred thousand human infections caused by zoonotic pathogen Hantavirus are diagnosed annually. In recent decades, repeated outbreaks of Hantavirus infections have occurred in Eurasia and America. In central China, the 
outbreaks of HTNV infection occur only when climatic conditions are favorable both for the growth of the rodent population and for transmission of the virus (Tian et al. 2017).

Hantavirus cardiopulmonary syndrome (HCPS) is a disease caused by Hantavirus, which is very virulent to humans. High temperatures and local plant growing, in particular sugar cane cultivation in tropical regions, can lead to spread of this virus. In the state of São Paulo, the average risk of Hantavirus is $1.3 \%$, with $6 \%$ of the 645 municipalities classified as high risk HCPS $\geq 5 \%$. Expansion of sugar cane plantations will increase the average risk of HCPS to $1.5 \%$, and up to $20 \%$ more risk-prone people. And temperature anomalies increase the risk of HCPS even more by $34 \%$ more people will be at risk (Prist et al. 2017).

Malaria and other diseases caused by mosquitoes are recorded in most tropical countries. Annually about 200 million cases of malaria occur, in the risk zone there are more than 3 billion people in Arica and Asia. The influence of higher temperatures and a large amount of precipitation traces quite clearly (WHO 2016).

For Dengue fever, changes in precipitation and humidity are associated with an increased risk in South and South East Asia and Africa (Patterson et al. 2016). Climate models predict that future climate change could affect the geographic range of the spread of Dengue fever in the Americas and Europe, and also in eastern China (Campbell et al. 2015).

An example of the effect of meteorological conditions on the occurrence of mass diseases is a malaria disease (Kurup et al. 2017). This disease is transmitted by a bite of the Anopheles mosquito from sick people and animals. The optimal places of mosquito breeding are standing or weakly flowing streams and reservoirs with clean water and well-developed vegetation well-warmed shoal water. The lowest temperature for optimum parasite development is the air temperature above $20{ }^{\circ} \mathrm{C}$. The lower the temperature, the shorter the period during which the parasite retains the ability to further develop. In a hot climate this disease is more widespread than in a mild climate, because at higher temperatures, the mosquito body contains an greater number of malarial parasites than at lower temperatures.

It is too early to say that the climate change impacts on infectious diseases caused by tick bites, particularly tick-borne encephalitis, because insufficient evidence. However, in the absence of periods of severe frost for several consecutive years, the range of vectors of the disease can expand, moving to the more northern regions of Russia, China, and Mongolia. More pronounced effect of climate warming, especially high temperature and humidity there is on the incidence of Lyme disease. From this point of view, it may be noted a 2.5-fold increase in the incidence rate in the Kaliningrad region (Russia) and in Belarus in 2003 compared with the year 2000 (Table 1).

In Belarus there is also an increase in the incidence of tick-borne encephalitis (TBE). For example, in the Grodno Oblast in 2005 the incidence rate was 1.7 per 100,000 people ( 20 cases), in $2009-2.4$ (27), in 2013 and $2014-4.1$ per 100,000 people (43 cases case per year). The index of complaints about bite of ticks in the Republic of 447.4 per 100,000 population) (Babayeva and Doroshenko 2015).

The average annual incidence of TBE (Tickborne encephalitis) in Karelia for the period from 1998 to 2013 was 7.2 per 100,000 of the population, 744 cases were registered. The incidence of LB averaged 6.8 per 100,000 , a total of 698 cases. The maximum indicator of TBE is 15.3 per 100,000 of the population - it was registered in 2003, LB (Lyme borreliosis) - 11.3 in 2004 (Sergeyev et al. 2015).

For 1971-2010 reproduction of I. Scapularis has increased in North America (2-5 times in Canada and 1.5-2 times in the United States of America). Warming in the northeastern part of North America could contribute to the emergence of the Lyme disease and in the future may result to its significant spread in new geographic regions and to increase the risk of spreading this natural focal tick disease (Ogden et al. 2014). 
Climate Change and Health, Table 1 Regional specificity of the morbidity of tick-borne encephalitis and Lyme disease during the period from 1999 to 2008 (Barinova et al. 2015)

\begin{tabular}{|c|c|c|c|c|c|}
\hline \multirow[b]{3}{*}{ Year } & \multicolumn{5}{|c|}{ Morbidity (per 100,000 population) } \\
\hline & \multicolumn{3}{|l|}{ Tick-borne encephalitis } & \multicolumn{2}{|l|}{ Lyme disease } \\
\hline & Kaliningrad region (Russia) & Karelia (Russia) & Belarus & Kaliningrad region (Russia) & Belarus \\
\hline 1999 & 1.3 & 4.4 & 0.3 & 8.2 & 1 \\
\hline 2000 & 1.2 & 5.6 & 0.2 & 19.9 & 1.9 \\
\hline 2001 & 1.2 & 6 & 0.6 & 7.8 & 1.8 \\
\hline 2002 & 1.2 & 7.2 & 0.2 & 7.2 & 1.8 \\
\hline 2003 & 3.8 & 15.2 & 0.5 & 22.7 & 5.1 \\
\hline 2004 & 1.3 & 11.6 & 0.4 & 13.3 & 5.2 \\
\hline 2005 & 1 & 9.2 & 0.5 & 13.2 & 5.4 \\
\hline 2006 & 0.9 & 7.6 & 1.1 & 20.9 & 9.1 \\
\hline 2007 & 0.8 & 8.8 & 0.8 & 20.8 & 6.7 \\
\hline 2008 & 0.8 & - & 0.7 & 12.5 & 6.6 \\
\hline Annual mean & 1.4 & 8.4 & 0.5 & 14.6 & 4.5 \\
\hline
\end{tabular}

\section{Climate and Allergens}

Temperature variability, increased air pollution, forest fires, droughts, and floods are all factors that can expose the population to the risk of respiratory diseases. Air quality has a measurable impact not only on morbidity, but also on the mortality of patients with asthma and other respiratory diseases.

The climate is the most important factor determining the timing of pollen transport by air and its type. Over the past 30 years, the prevalence of allergies and asthma caused by airborne allergens in Europe has increased fourfold, according to WHO about 235 million people suffer from asthma.

It is expected that global warming will affect the onset, duration, and intensity of the pollen season, on the one hand, and rates of exacerbation of asthma due to air pollution, respiratory infections, and/or inhalation of cold air on other hand. (D'Amato et al. 2015).

Sharp interannual fluctuations of hydrothermal conditions cause the expressed variations in terms of vegetation development. In Kaliningrad (Russia), during the current warming in 2012, compared to 1893 , there was a significant shift in the dates of the blooming of spring plants (Taraxacum officinale, Lamium album, Pyruscommunis L., Malus P. Mill., etc., for an average of 12 days), the duration of the active vegetation period of plants over the last 30 years grows with a trend of 4.89 days/10 years, which can increase the risk of allergic reactions (Barinova and Kokhanovskaya 2015).

\section{Threats to Mental Health}

In covering climate change issues in the popular press, relatively little attention has been paid to one aspect: mental health. The rise in the ocean level, the increasingly violent storms, and the more ferocious droughts caused by climate change not only destroy physical infrastructure, but also affect people in other ways: people lose their homes, their work, their family members, and their community. The researchers found that climate change can cause not only posttraumatic stress disorder (PTSD) from extreme weather events, such as Hurricane Katrina, but also a "pretraumatic" stress condition (Gifford and Gifford 2016). Climate change is harmful to mental health, which is the most significant among people in disadvantaged situations (including those with existing mental illnesses) (Every-Palmer et al. 2015). Mental health can be affected not only by climate change, weather damage to infrastructure, a direct impact on physical health, but also by indirect impact of the media, research and 
policy and by exacerbating existing stresses (Willox et al. 2014).

Classification of weather events and their effects on mental health is proposed in Bourque and Willox (2014). Acute or extreme weather events (hurricanes, severe storms, floods) have direct effects trauma and death, acute stress and traumatic reactions, increased risk of posttraumatic stress disorders; and indirect effects damage/loss of home and infrastructure, destruction of community and health resources, forced relocations, consequences of injuries and concomitant illness.

Subacute weather events such as droughts, heat waves have direct effects exacerbating heat-related preexisting mental health problems and increase the level of aggressive behavior; indirect effects unemployment, the strengthening of socio-economic disparities and tensions in the community, migration and urban migration. Long-term changes in the natural environment (desertification, soil erosion, and biodiversity loss) can lead to loss of livelihoods, involuntary migration, and related mental disorders.

The impact of climate change on health can be multiplicative. For example, high temperatures cause a primary health impact with a thermal shock; they can also worsen labor productivity and reduce farm productivity. These effects are also interlinked with more general social trends economic migrants from South Asia are already faced with poor living conditions, including inadequate sanitation and possible conflicts with host communities (Singh et al. 2016).

\section{New and Returning Infections}

Emergent infections are defined as "diseases that have recently emerged among the population, or existed before, but have significantly increased the number of cases, or have spread in a new geographic region" (Morse 2001).

In connection with the globalization of processes on the planet, new and recurring infections have become an international problem (Malkhazova 2017). The Crimean hemorrhagic fever, Ebola, Lasa and Marburg fever, SARS, Middle Eastern coronavirus syndrome, Nipah virus infection, and Rift-Fali fever were included in the list of the most urgent emergent diseases in the world. Three other diseases were called "serious" - chikungunya, severe fever with thrombocytopenia syndrome, and Zika.

Other diseases with epidemic potential, such as HIV/AIDS, tuberculosis, malaria, avian influenza, and dengue fever, were not included in the list, as for these infections there are basic systems of control and research (WHO 2017c). The risk of infections in the opinion of some authors is increasing, including due to global climate changes that contribute to the penetration of disease vectors into new areas, for example, mosquitoes that transmit viral infections (Dengue fever, chikungunya, Zika virus, etc.) (Rochlin et al. 2013; Kraemer et al. 2015; Campbell et al. 2015).

The incidence caused by the West Nile virus in Israel may be associated with extremely high temperatures. In Volgograd (Russia), the number of people affected by this infection is greater in the years with mild winters and hot summers. In Brisbane, Australia, climate models shows that monthly precipitation is associated with the transmission of Ross River virus (RRV). Finally, with the increase in average rainfall combined with high tides, there was an extremely large increase in the Aedes vigilax mosquito population along the southern coast of New South Wales, Australia, and with outbreaks of BFV (Barmah Forest virus) disease (Andersen and Davis 2016).

The West Nile Fever Virus (WNV) is the most widely spread among encephalitic flaviviruses. The transmission cycle of this virus exists in rural and urban areas, in which it infects birds, humans, horses, etc. Many factors influence its transmission and distribution, related to dynamics and interaction between the pathogen, hosts, vector, and environment.

Direct and indirect weather conditions affect the vector ability to acquire, maintain, and transmit the virus, the dynamics of the population, and the rate of viral replication in the mosquito. The importance of climatic factors (temperature, precipitation, relative humidity, and winds) as drivers of the epidemiology of WNV increases in the face of their anomalous changes. Particularly high air temperatures and fluctuations in precipitation 


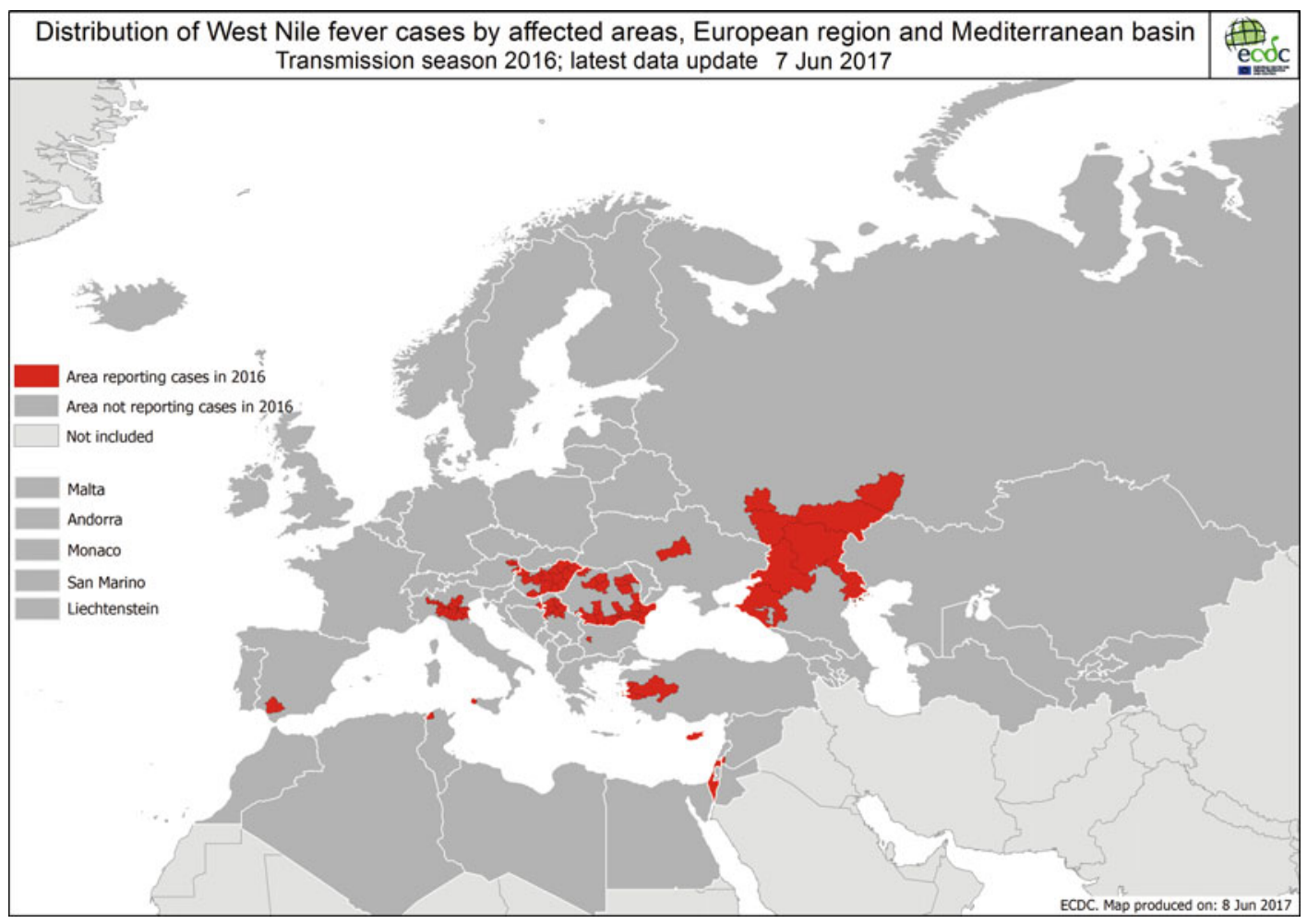

Climate Change and Health, Fig. 2 West Nile fever cases by affected areas in Europe and the Mediterranean, 2016, transmission season (European Centre for Disease
Prevention and Control 2017) (C) European Centre for Disease Prevention and Control (ECDC) 2019

Chicago). Heat stress will entail respiratory diseases (asthma, etc.) aggravated by air pollution and aeroallergens such as asthma; viral infections and vector-borne diseases, and water-transmitted diseases, such as diseases of the gastrointestinal tract; mental health disorders, depression, etc. (Patz et al. 2014).

In the Arctic, even more than in other parts of the world, temperature and humidity affect the rate of development and propagation of pathogens for the prevalence and cyclicity of infectious diseases. High winter temperatures allow infected host species to survive in larger numbers and expand their habitat. However, the impact of these changes on human diseases has not yet been sufficiently assessed. In addition climate change can affect individual populations if, for example, the ice situation undermines hunting and related food security (Ford 2014).

\section{Regional Aspects of Climate Change and Health}

According to the conclusions of international experts, by 2050 many cities in the USA will be subject to more frequent effects of extremely hot days are strongly associated with exceeding the concentration of ground-level ozone (e.g., in 
The geographical and temporal distribution of a number of infectious diseases may change in the future. Many infectious diseases are very sensitive to climate. Their appearance in the region also depends on climate change-related environmental changes. Diseases can be spread by humans and animals, including arthropods. Many zoonotic pathogens of the circumpolar type are potentially sensitive to the climate: Brucella spp., Toxoplasma gondii, Trichinella spp., Clostridium botulinum, Francisella tularensis, Borrelia burgdorferi, Bacillus anthracis, Echinococcus spp., Leptospira spp., Giardia spp., Cryptosporida spp., Coxiellaburnetti, viruses of rabies, West Nile, hantaviruses, and tick-borne encephalitis (Parkinson et al. 2014).

Zoonotic parasitic diseases are increasingly affecting the human population due to the effects of globalization, urbanization, and climate change (Gordon 2016). Mass distribution of one of the most dangerous and very widespread human diseases, i.e., ascariasis (caused by parasitic worms), depends to a considerable extent on the degree and seasonality of the humidification of the area by precipitation. Model of the Ascaris lumbricoides transmission risk in East Africa shows the greatest risk in savannas and forest tropical areas and the lowest risk in arid and semi-arid regions (Gentry et al. 2016).

Climatic factors significantly differ spatially and in time, which is due to solar radiation, peculiarities of atmospheric circulation, composition and structure of the underlying surface. Geographic regions differ in climatic parameters, depending on the latitude, distance from the oceans, the height of the terrain, which affects the structure and nature of the incidence of the population. In Polar Regions, with the features of the light regime (polar night and day), ultralow air temperature, strong winds prevail catarrhal disease, frostbite, weakening the immune system, the symptom of "psycho-emotional" voltage, meteorological stress. In arid regions with a prolonged hot period, intense insolation, sharp daily fluctuations in temperature and humidity are most frequent: heat strokes, respiratory and cardiovascular problems, and pathologies of the skin.
Man, in its origin, the being of the tropical zone in reproductive terms does not depend on the seasons of the year. Thanks to clothing and comfortable housing, it is partially isolated from natural climatic conditions. Therefore, the effect of the seasons of the year on humans compared to animals is less pronounced.

In hot climates of the Earth, a season of extremely hot weather is very important for a man and in monsoon zones periodic changes in the rainy season and dry seasons. In polar climates, the priority role is played by the presence of a polar day and night, heat deficit, and ultraviolet radiation. In temperate climates, seasonality is most pronounced in the spring renewal of nature and the need for survival in the season of frosty winter weather.

Therefore, the influence of light and heat factors as stimulators of the formation of the seasonal cycle of physiological functions affecting physicochemical processes is noted both in the north and in the south.

It goes without saying that for the formation of physiological reactions, in addition to climate, the quality of summer and winter nutrition, the state of motor activity, the possibility of being outdoors, the age and way of life of a man can be important. Climatopathic effects - the property of living organisms to react to seasonal manifestations and territorial features of macroclimate. In terms of medical climatology, the characteristics of physiological reactions, clinical disorders, exacerbation of diseases, and mortality are often called climatopathology (climatopathy).

Most diseases in extratropical countries concentrated in the colder months, leaving as, for example, for the UK, the warm season almost free from diseases. In winter maximum of diseases and mortality in countries with a weakly continental temperate and subtropical climate (France, Denmark, USA, etc.) can be explained by the general cold discomfort characteristic of the cold season. At low temperatures, especially during periods of cold stress, the body's regulatory systems in stressful winter weather conditions do not adapt as quickly and clearly as it does under heat stresses during the warm period. In addition, the probability of occurrence of 
weather heat stress in countries with a temperate climate is not so high, but it increases due to its warming.

\section{Conclusions and Prospects}

The Intergovernmental Panel on Climate Change is confident that there will be an increase in the frequency of daily extreme high temperatures, heat waves, and frequency of floods will increase in intensity in the twenty-first century. The last decades are characterized by a distinct dynamics of changes in human diseases in comparison with the beginning of the twentieth century. The leading causes of death of people of working age in developed countries are diseases of the cardiovascular system, myocardial infarction, and stroke. Expanding the areal of especially dangerous infections and other diseases confirms the thesis of the existence of global risks of increasing the incidence of the population, which can lead to huge costs for the national economies of many developing countries.

In 2015, the UN General Assembly proposed an action plan of 17 sustainable development goals for the period up to 2030, which provides for the integrated nature and balance of all three components: economic, social, environmental.

A major role in reducing mortality from infections is played by the actions of local authorities to eliminate the causes of infection and provide medical care to all segments of the population.

The outbreak of dengue fever in Lahore, Pakistan, in 2011 led to 300 deaths. The strategy adopted by the provincial government and including Institutional, Technological, Environmental Capacity Building Measures and the improvement of medical infrastructure was successful in 2012 only 252 cases of dengue fever without fatalities were reported (Khan and Abbas 2014).

Also in Sri Lanka Dengue is leading public health problem. The average annual incidence is $175 / 100,000$ population. Harnessing the World Health Organization Global strategy for dengue prevention and control, 2012-2020, Sri Lanka has pledged to achieve a mortality from dengue below $0.1 \%$ and to reduce morbidity by $50 \%$ (from the average of the last 5 years) by 2020. National guidelines with enhanced diagnostics have significantly improved clinical management of dengue, reducing the case-fatality rate to $0.2 \%$ (Tissera et al. 2016).

Adaptation measures to climate change are obvious - it is the eradication of poverty, the improvement of health services, the formation of a healthy lifestyle, as well as taking measures to reduce the human impact on the climate system, the transition to clean green energy, and transport. It is very important to increase the dissemination of science-based information on adverse climatic and weather events and the introduction of warning systems in order to help each of us, as well as health authorities take preventive protective measures to protect public health in the context of periodic climate change.

Thus, the WHO and WMO initiatives on meningitis (MERIT) and leptospirosis (GLEAN) are examples of an innovative framework for disease control strategies. The Glean network, approved in 2010, brings together representatives of international organizations, including foundations and research institutes, and offers opportunities to reduce the risk and consequences of leptospirosis outbreaks in populations at high risk. Leptospirosis is a complex and serious problem. It was estimated that there are annually 1.03 million clinical cases and 58,900 deaths due to leptospirosis worldwide. It is assumed that the scale of climate change, in particular floods, can lead to an intensification of outbreaks. The Global Environmental Action Network on Leptospirosis GLEAN offers sample opportunities to reduce the risk of integrating knowledge in the field of health preservation (GLEAN 2018). The MERIT, Meningitis Environmental Risk Information Technologies initiative, promotes the use of climate information for short-term forecasting of risk of meningitis in Africa (MERIT 2018). A high mortality rate led to the development of the EUROHEAT project, within which a quantitative assessment of the health effects of heat was conducted and options were identified for improving the health systems' preparedness for and response to heat waves WHO (2009). 
An important element for reducing the occurrence or frequency of diseases is raising awareness. The Global vector control response (GVCR) 2017-2030 approved by the World Health Assembly (2017b) provides strategic guidance to countries and development partners for urgent strengthening of vector control as a fundamental approach to preventing disease and responding to outbreaks. To achieve this, a re-alignment of vector control programs is required, supported by increased technical capacity, improved infrastructure, strengthened monitoring and surveillance systems, and greater community mobilization (WHO 2017b). The World Health Organization (WHO), United Nations Children's Fund (UNICEF), the United Nations Development Programme (UNDP), the World Bank and WHO support TDR, the Special Programme for Research and Training in Tropical Diseases is a global program of scientific collaboration that helps facilitate, support, and influence efforts to combat diseases of poverty (TDR 2017).

Asia Pacific Leaders Malaria Alliance (APLMA) is an alliance of heads of government to accelerate progress in the fight against malaria and eliminate it in the region by 2030 . The APLMA malaria elimination roadmap prioritizes research and innovation, policy alignment and program coordination, regulatory cooperation, and funding and management of malaria response (APLMA 2017).

For malaria mitigation strategies, countries in Africa and Asia monitor conditions favorable for malaria outbreaks: seasonal rainfall forecasts and health information (WHO 2012). This approach ensures the advance distribution of drugs, insecticides, mosquito nets to vulnerable groups of the population.

In 2015, the World Health Assembly endorsed a new Global Technical Strategy for Malaria 2016-2030. A key milestone for 2020 is the elimination of malaria in at least ten countries that had the disease in 2015 (WHO 2018a). In May 2016, the World Health Assembly adopted the first "Global Health Sector Strategy for Viral Hepatitis for 2016-2021." The strategy emphasizes the critical role of universal coverage of health services, and its objectives are in line with the Sustainable Development Goals.

The vision of eliminating viral hepatitis as a public health problem is embodied in a global goal aimed at reducing the number of new viral hepatitis infections by $90 \%$ and reducing the death rate from viral hepatitis by $65 \%$ by 2030 (WHO 2017a).

Due to a global climate change, probable public health problems go far beyond the obvious direct impact - they are most evident among the poor population in areas with poor health care, a high incidence of other negative factors (malnutrition, smoking, etc.), that reduce the body's ability to resist. Understanding the multifactorial impact on health is the basis for taking protective measures, addressing short-term and long-term tasks, taking effective measures by governments and international organizations (WHO, WMO, UNDP, etc.).

\section{Cross-References}

- Climate Change Refugees and Health Implications

Holistic Wellbeing: Mental, Physical, and Spiritual

- Migration and Health

- Neglected Tropical Diseases

- Public Health and Sustainability

Urban Development and Health

Urban Sustainability and Human Health

\section{References}

Andersen LK, Davis MDP (2016) Climate change and the epidemiology of selected tick-borne and mosquito-borne diseases: update from the International Society of Dermatology Climate Change Task Force. Int J Dermatol 56:252-259. https://doi.org/10.1111/ijd.13438

APLMA (2017) What is APLMA? http://aplma.org/whowe-are/what-is-aplma.html. Accessed 21 Sept 2018

Babayeva IV, Doroshenko EM (2015) Opredeleniyeurovnyaserotonina v likvorepatsiyentov s kleshchevymentsefalitom. Sovremennyye dostizheniya molodykh uchonykh $\mathrm{v}$ meditsine: sbornik materialov II Respublikanskoy nauchno-prakticheskoy konferentsii 
s mezhdunarodnym uchastiyem. GrGMU, Grodno, pp 8-10

Baker-Austin C, Trinanes J, Gonzalez-Escalona N, MartinezUrtaza J (2017) Non-cholera vibrios: the microbial barometer of climate change. Trends Microbiol 25:76-84. https://doi.org/10.1016/j.tim.2016.09.008

Barinova G, Kokhanovskaya M (2015) Climate change monitoring on the basis of phytophenological observations in Kaliningrad region. Pollut Atmos. https://doi. org/10.4267/pollution-atmospherique.5009. Accessed 1 Apr 2018

Barinova GM et al (2015) Changes of South Baltic Region climate: agroecological challenges and responses. Springer, Berlin. https://doi.org/10.1007/978-3-64238670-1_17. Accessed 11 Apr 2018

Bourque F, Willox AC (2014) Climate change: the next challenge for public mental health? Int Rev Psychiatry 26:415-422. https://doi.org/10.3109/ 09540261.2014 .925851

Campbell LP et al (2015) Climate change influences on global distributions of dengue and chikungunya virus vectors. Philos Trans R Soc B Biol Sci 370 (1665):20140135. https://doi.org/10.1098/ rstb.2014.0135

D'Amato G et al (2015) Meteorological conditions, climate change, new emerging factors, and asthma and related allergic disorders. A statement of the World Allergy Organization. World Allergy Organ J 8:25. https:// www.ncbi.nlm.nih.gov/pubmed/26207160. Accessed 8 Apr 2018

European Centre for Disease Prevention and Control (2017) West Nile fever cases by affected areas in Europe and the Mediterranean, 2016 transmission season. European Centre for Disease Prevention and Control. (C) European Centre for Disease Prevention and Control (ECDC) 2019 https://ecdc.europa.eu/en/publi cations-data/west-nile-fever-cases-affected-areas-euro pe-and-mediterranean-2016-transmission. Accessed 5 Apr 2018

Every-Palmer S et al (2015) Climate change and psychiatry. Aust N Z J Psychiatry. https://doi.org/10.1177/ 0004867415615946. Accessed 14 Apr 2018

Fann N et al (2014) The geographic distribution and economic value of climate change-related ozone health impacts in the United States in 2030. J Air Waste Manag Assoc 65(5):570-580

Ford JD (2014) Adapting to the effects of climate change on Inuit health. Am J Public Health 104:e9-e17. https:// doi.org/10.2105/AJPH.2013.301724. Accessed 30 Mar 2018

Galway LP et al (2015) Hydroclimatic variables and acute gastro-intestinal illness in British Columbia, Canada: a time series analysis. Water Resour Res 51:885-895. https://doi.org/10.1002/2014wr015519

Gentry J et al (2016) Predictive mapping of transmission risk of a soil-transmitted helminth across east Africa: findings from community prevalence surveys. J Public Health Dev Countries 2:150-161
Gifford E, Gifford R (2016) The largely unacknowledged impact of climate change on mental health. Bull At Sci 72:292-297. https://doi.org/10.1080/00963402.2016.121 6505. Accessed 17 Apr 2018

GLEAN (2018) Leptospirosis. https://sites.google.com/ site/gleanlepto/home. Accessed 19 Sept 2018

Gordon CA (2016) The increase of exotic zoonotic helminth infections: the impact of urbanization, climate change and globalization. Adv Parasitol 91:311-397

Grigoŕyeva EA (2014) Volnytepla v Khabarovskeizdorov'yenaseleniya. Izv Samarskogonauchnogotsentra Rossiyskoy Akad Nauk 5(2):843-846

Hajat S et al (2014) Climate change effects on human health: projections of temperature-related mortality for the UK during the 2020s, 2050s and 2080s. J Epidemiol Community Health 68:641-648. https://doi.org/ 10.1136/jech-2013-202449

Hay RJ, Johns NE, Williams HC et al (2014) The global burden of skin disease in 2010: an analysis of the prevalence and impact of skin conditions. J Investig Dermatol 134:1527-1534. https://doi.org/10.1038/ jid.2013.446

IPCC (2007) Climate Change 2007: The Physical Science Basis. Contribution of Working Group I to the Fourth Assessment Report of the Intergovernmental Panel on Climate Change [Solomon, S., D. Qin M. Manning Z. Chen M. Marquis K.B. Averyt M. Tignor H.L. Miller (eds.)]. Cambridge University Press, Cambridge, United Kingdom and New York, NY, USA, 996 pp. https://www.ipcc.ch/site/assets/uploads/2018/05/ar4_ wg1_full_report-1.pdf

IPCC (2013) Fifth assessment report - climate change. https://www.ipcc.ch/report/ar5/wg1/. Accessed $10 \mathrm{Apr}$ 2018

Johnson RJ, Stenvinkel P, Jensen T et al (2016) Metabolic and kidney diseases in the setting of climate change, water shortage, and survival factors. J Am Soc Nephrol 27:2247-2256. https://doi.org/10.1681/asn.2015121314

Khan IA, Abbas F (2014) Managing dengue outbreak in Lahore, Pakistan: efficacy of government response and lessons for the future. J Health Manag 16(4):471-480

Kokorin AO (2014) Izmeneniyeklimata: obzorPyatogootsenochnogodoklada MGEIK. Vsemirnyy fond dikoyprirody. Moskva, p 80

Kraemer MU, Sinka ME, Duda KA et al (2015) The global distribution of the arbovirus vectors Aedesaegypti and Ae. albopictus. elife 4:e08347

Kurup R et al (2017) Malaria trend and effect of rainfall and temperature within Regions 7 and 8, Guyana. http://www.dipterajournal.com/pdf/2017/vol4issue6/ PartA/4-4-5-421.pdf

Malkhazova SM (2017) Novyye I vozvrashchayushchiyesya infektsii v Rossii: mediko-geograficheskiy aspekt. Vestn Moskov Univ 5:24-32

Meehl GA, Stocker TF, Collins WD, Friedlingstein P, Gaye AT, Gregory JM, Kitoh A, Knutti R, Murphy JM, Noda A, Raper SCB, Watterson IG, Weaver AJ, Zhao Z.-C. (2007) Global Climate Projections. Figure 10.8. In: Climate Change 2007: The Physical Science Basis. 
Contribution of Working Group I to the Fourth Assessment Report of the Intergovernmental Panel on Climate Change [Solomon, S., D. Qin, M. Manning, Z. Chen, M. Marquis, K.B. Averyt, M. Tignor and H.L. Miller (eds.)]. Cambridge University Press, Cambridge, United Kingdom and New York, NY, USA. https:// archive.ipcc.ch/report/graphics/index.php?t=Assessme nt $\% 20$ Reports\&r=AR4\%20-\%20WG1\&f=Chapter $\%$ 2010

MERIT (2018) Meningitis environmental risk information technologies (MERIT) project. http://merit.hcfoundation.org/aboutMERIT2012.html. Accessed 10 Sept 2018

Morse S (2001) Factors in the emergence of infections disease. Plagues and politics. Palgrave Macmillan, London, pp 8-26

Newton JN et al (2015) Changes in health in England, with analysis by English regions and areas of deprivation, 1990-2013: a systematic analysis for the Global Burden of Disease Study 2013. Lancet. https://www. sciencedirect.com/science/article/pii/S0140673615001 956. Accessed 30 Apr 2018

Ogden NH et al (2014) Estimated effects of projected climate change on the basic reproductive number of the Lyme disease vector Ixodesscapularis. Environ Health Perspect 122(6):631

Parkinson AJ et al (2014) Climate change and infectious diseases in the Arctic: establishment of a circumpolar working group. Int J Circumpolar Health 73:25163. https://doi.org/10.3402/ijch.v73.25163

Patterson J et al (2016) Dengue, Zika and chikungunya: emerging arboviruses in the New World. Western Journal of Emergency Medicine 17(6):671

Patz JA et al (2014) Climate change. JAMA 312:1565. https://doi.org/10.1001/jama.2014.13186

Paz S (2015) Climate change impacts on West Nile virus transmission in a global context. Philos Trans R Soc B Biol Sci 370:20130561. https://doi.org/10.1098/ rstb.2013.0561

Prist PR et al (2017) Climate change and sugarcane expansion increase Hantavirus infection risk. PLoS Negl Trop Dis. https://doi.org/10.1371/journal.pntd.0005705

Rochlin I et al (2013) Climate change and range expansion of the Asian Tiger mosquito (Aedesalbopictus) in Northeastern USA: implications for public health practitioners. PLoS One. https://doi.org/10.1371/journal. pone. 0060874

Sergeyev AM et al (2015) KleshchevoyentsefalitiLaymborrelioz v RespublikeKareliya (sovremennyyeaspektyklinikiiepidemiologii). UchenyyezapiskiPetrozavodskogogosudarstvennogouniversiteta. Biol Nauki 4(149):34-36
Singh $M$ et al (2016) Climate change, health and future well-being in South Asia. Climate change and human health scenario in South and Southeast Asia advances in Asian human-environmental research. pp 11-27. https://doi.org/10.1007/978-3-319-23684-1_2

TDR (2017) Climate change research findings provided for policy discussions in Africa. http://www.who.int/tdr/ news/2017/climate-change-research-findings-policy-af rica/en/. Accessed 10 Sept 2018

Tian $\mathrm{H}$ et al (2017) Interannual cycles of Hantaan virus outbreaks at the human-animal interface in Central China are controlled by temperature and rainfall. Proc Natl Acad Sci 114:8041-8046. https://doi.org/10.1073/ pnas. 1701777114

Tissera $\mathrm{H}$ et al (2016) Sustainable dengue prevention and control through a comprehensive integrated approach: the Sri Lankan perspective. WHO South-East Asia J Public Health 5(2):106

WHO (2009) EuroHEAT. http://www.euro.who.int/_data/ assets/pdf file/0009/95913/E92473.pdf?ua=1. Accessed 20 Sept 2018

WHO (2011) World malaria report: 2011. https://www. who.int/malaria/publications/atoz/9789241564403/en/

WHO (2012) Atlas of health and climate. http://www.who. int/globalchange/publications/atlas/report/en/. Accessed 17 Sept 2018

WHO (2016) Eliminating malaria. In: (c) World Health Organization 2016. https://apps.who.int/iris/ bitstream/handle/10665/205565/WHO_HTM_GMP 2016.3 eng.pdf? sequence $=1 \&$ isAllowed $=y$

WHO (2017a) Hepatitis A. http://www.who.int/ru/newsroom/fact-sheets/detail/hepatitis-a. Accessed $15 \mathrm{Sept}$ 2018

WHO (2017b) Vector-borne diseases 2017. http://www. who.int/news-room/fact-sheets/detail/vector-borne-dis eases. Accessed 28 Apr 2018

WHO (2017c) WHO publishes list of top emerging diseases likely to cause major epidemics. In: World Health Organization. http://www.who.int/medicines/ebola-treatment/ WHO-list-of-top-emerging-diseases/en/. http:/www. who.int/medicines/ebola-treatment/WHO-list-of-top-eme rging-diseases/en/. Accessed 12 Apr 2018

WHO (2018a) Q\&A on the E-2020 initiative and malaria elimination http://www.who.int/malaria/media/e-2020initiative-qa/en/. Accessed 12 Sept 2018

WHO (2018b) What is the WHO definition of health? http:// www.who.int/suggestions/faq/en/. Accessed 29 Apr 2018

Willox AC et al (2014) Examining relationships between climate change and mental health in the Circumpolar North. Reg Environ Chang 15:169-182. https://doi.org/ 10.1007/s10113-014-0630-z. Accessed 30 Apr 2018 